\title{
Development of a New Smartphone Application to Increase Dietary Compliance in Patients with Chronic Kidney Disease
}

\author{
Kronik Böbrek Hastalığı Olan Hastalarda Diyet Uyumunu Artıracak Yeni Bir Akıllı Telefon \\ Uygulamasinin Geliştirilmesi
}

\section{Feray Gençer Bingöl1, Makbule Gezmen Karadağ², Mustafa Can Bingöl ${ }^{3}$, Yasemin Erten ${ }^{4}$}

Geliş tarihi/Received: 27.10.2021 • Kabul tarihi/Accepted: 29.12.2021

\begin{abstract}
Aim: Nutritional therapy in chronic kidney disease (CKD) requires certain regulations in the diet of the patients. Patients' self-management becomes possible with the development of mobile phones and their software. In the current study, a smartphone application that could be used to increase dietary compliance of CKD stage 4-5 and hemodialysis patients was developed. It is aimed that patients can control the dietary intake of energy, protein, sodium, potassium, phosphorus, and fluid by using the developed mobile application.

Subjects and Method: The mobile application has been developed by the researchers until the final control and test phase. Later, the final control and test phase of the developed application were carried out by 5 expert dietitians, 5 specialist doctors, and 5 hemodialysis patients.

Results: The majority of the participants stated that the application was easy to use, interesting, visually well designed, contains sufficient reliable information, and that they can recommend it to other patients. Participants who examined the application also offered suggestions about the application.

Conclusion: The application was updated according to the evaluations and suggestions of the participants. The final application was formed to be ready for the use of the patients.
\end{abstract}

Keywords: Smartphone applications, nutrition, hemodialysis, chronic kidney disease, mobile technology

\section{ÖZET}

Amaç: Kronik böbrek yetmezliğinde beslenme tedavisi, hastaların diyetinde belirli düzenlemeler yapılmasını gerektirmektedir. Hastaların kendi kontrollerini sağlayabilmesi cep telefonlarının ve yazılımlarının gelişmesiyle mümkün hale gelmektedir. Bu çalışmada kronik böbrek yetmezliği 4-5. evre ve hemodiyaliz tedavisi alan hastaların diyete uyumunu artırabilecek bir akıllı telefon uygulaması geliştirilmiştir. Geliştirilen uygulama ile hastaların diyetle alınan enerji, protein, sodyum, potasyum, fosfor ve sıvı alımını kontrol edebilmesi amaçlanmaktadır.

Bireyler ve Yöntem: Uygulama, son kontrol ve test aşamasına kadar araştırmacılar tarafından geliştirilmiştir. Daha sonra geliştirilen uygulamanın son kontrol ve test aşamasına 5 uzman diyetisyen, 5 uzman doktor ve 5 hemodiyaliz hastası dahil edilmiştir.

1. İletişim/Correspondence: Gazi Üniversitesi, Sağllk Bilimleri Fakültesi, Beslenme ve Diyetetik Bölümü, Ankara, Türkiye

E-posta: gencerferay@gmail.com • •

2. Gazi Üniversitesi, Sağlık Bilimleri Fakültesi, Beslenme ve Diyetetik Bölümü, Ankara, Türkiye • • ㄴ https://orcid.org/0000-0003-3202-3250
3. Firat Üniversitesi, Teknoloji Fakültesi, Mekatronik Mühendisliği, Elazığ, Türkiye ○ https://orcid.org/0000-0001-5448-8281

4. Gazi Üniversitesi, Tıp Fakültesi, Nefroloji Bilim Dalı, Ankara, Türkiye ㄴ) https://orcid.org/0000-0002-4073-5525 
Bulgular: Katılımcıların çoğunluğu uygulamanın kullanımının kolay olduğunu, ilgi çekici olduğunu, görsel olarak iyi tasarlandığını, yeterli-güvenilir bilgiler içerdiğini ve diğer hastalara tavsiye edebileceklerini belirtmişlerdir. Uygulamayı inceleyen katılımcılar uygulama hakkında önerilerde de bulunmuştur.

Sonuç: Uygulama, katılımcıların değerlendirme ve önerileri doğrultusunda güncellenmiştir. Uygulamanın son hali hastaların kullanımına hazır hale getirilmiştir.

Anahtar kelimeler: Akıllı telefon uygulaması, beslenme, hemodiyaliz, kronik böbrek yetmezliği, mobil teknoloji

\section{INTRODUCTION}

Increasing number of chronic kidney disease (CKD) patients posing enormous challenges to society (1). Applied medical nutrition therapy varies according to the patient's condition and requires certain restrictions and regulations in the nutrition of the patient $(2,3)$.

Smartphones and smartphone applications have started to take a large place in our lives with the developing technology (4). Smartphone applications, which have also started to be developed in the field of health, aim to provide self-management for patients and to facilitate their lives in addition to professional support $(5,6)$. Especially, mobile applications related to nutrition come to the fore in chronic diseases where the course of the disease improves with nutrition therapy $(7,8)$. Smartphone applications that keep a food diary, offer recipes suitable for dietary restrictions of the disease and aim to control the nutritional intake of the patients have started to be developed for CKD, which is one of the chronic diseases (9).

In this study, it was aimed to develop a smartphone application specific to nutritional therapy of CKD patients.

\section{SUBJECTS AND METHOD}

\section{Developing of the Application}

Firstly, the application to be made was planned, the necessary analyses were formed, and finally, suitable platforms for software development were determined. Later, the plan, analysis, and selected platform were checked by the researchers and the risk analysis was evaluated with pros and cons. The graphical user interface (GUI) of the software was designed to produce the first prototype. The GUI was evaluated by the researchers. The necessary code of the software was written according to the evaluation. The first prototype of the application developed was controlled and tested. After the test and control steps, researchers performed the required risk analysis. Then, the second prototype of the application has started to be produced. Some deficiency of the GUI was noticed after the test and control steps. The GUI of the application was updated to remedy the deficiency and the updated GUI was approved by the researchers. The program accuracy was tested by entering the determined menus to the program after the necessary codes were written. The final control and test phase of the developed application were carried out by expert dietitians, specialist doctors, and patients. Writing the code of the final program was started after the researchers made the last risk analysis and GUI operations. Unit control was made after the required code was written. After this stage, the final application that could be used by the patients was ready. The developed program is an application for smart Android mobile phones. The application was developed in the Android Studio environment and the Android 9.0 (Pie) version was preferred due to its widespread use (10).

\section{Content of the Application}

Patients can calculate the intake of energy, protein, sodium, potassium, phosphorus, and fluid with the developed application by entering the daily food intake into the application. The energy and nutrient contents of foods were defined by the researchers 
for the application. In particular, upper limits for the restricted intake of sodium, potassium, phosphorus, and fluid were defined in the application and the application warns patients who exceeded the intake limit to be careful. After the warning, patients can switch to the recommendation screen and see the recommendations for nutrients exceeding the intake limit. The recommendations of energy, nutrients, and fluids were determined based on the guideline of the National Kidney Foundation (11).

Nutrition database was created for this mobile application and nutrient contents of foods in this database were taken from the Beslenme Bilgi Sistemi (BeBİS [Nutrition Information System]) program (12). The energy, nutrients (protein, sodium, potassium, and phosphorus), and fluid amounts of meals in this database were calculated by forming the portion contents. The amount of the foods included in the meals was taken from Türk Mutfağından Örnekler (Examples from Turkish Cuisine), Standart Yemek Tarifeleri (Standard Recipes), and Geleneksel Türk Mutfağından Seçmeler: Besin Ögeleri Açısından Değerlendirilmesi (Selections from Traditional Turkish Cuisine: Evaluation in terms of Nutrients) (13-15). All meals included in the database were calculated without salt. In the application, the measurement of foods and meals such as tablespoons, teaspoons, dessert spoons, water glasses, small size, large size, pieces, slices, bowls, and portions were performed by using units that were understandable by the patients. Yemek ve Besin Fotoğraf Kataloğu (Meal and Food Photo Catalog) was used to determine the measurements and amounts defined in the application (16).

\section{Sampling}

After developing the application, 5 expert dietitians, 5 specialist doctors, and 5 patients were asked to examine and evaluate the application. Participants were asked to evaluate the application in terms of its content and competence with the questionnaire form. In addition, suggestions to improve the application were collected from healthcare professionals and patients. The collected suggestions and evaluations regarding the application constituted the final control and testing phase of the application. After the evaluation phase, the application was updated in light of the suggestions.

\section{Evaluation of the Data}

The data were evaluated using the SPSS version 22.0 package program. Number (n) and percentage values (\%) for qualitative data, mean $(\overline{\mathrm{X}})$, standard deviation (SD), median, minimum (Min), and maximum (Max) values were calculated for quantitative data.

\section{RESULTS}

The application was examined by 5 expert dietitians, 5 specialist doctors, and 5 patients to perform the final control and test of the application. Participants that examined the application were $33.3 \%$ men and $66.7 \%$ women. The average age of the participants was $37.3 \pm 9.22$ years and the average education span was $18.5 \pm 5.63$ years. It was stated that the application was easy to use by $60 \%$ of expert dietitians, $100 \%$ of specialist doctors, and $80 \%$ of patients. Eighty percent of expert dietitians and specialist doctors and all patients found the application content interesting. When the application was evaluated visually, 60\% of the expert dietitians, all specialist doctors, and patients stated that the application was visually well designed. All participants thought that the application contained sufficient information. The reliability of the information in the application was asked to be evaluated only by health professionals. Both dietitians and doctors stated that the information in the application was reliable. All participants stated that the application would be beneficial and therefore could be recommended to other patients. Participants were asked to give points from 1 (very poor) to 5 (very good) for the application. Expert dietitians, specialist doctors, and patients gave $4.4 \pm 0.89,4.8 \pm 0.45,5.0 \pm 0.00$ points to the application as average, respectively and total average points of the application was calculated as $4.7 \pm 0.59$ points. General information of the participants and suggestions about the application were given in Table 1. 
Tablo 1. General information and suggestions about the application of expert dietitians, specialist doctors, and patients

\begin{tabular}{|c|c|c|c|c|}
\hline & $\begin{array}{c}\text { Expert Dietitian } \\
\text { (n:5) }\end{array}$ & $\begin{array}{c}\text { Specialist Doctor } \\
(\mathrm{n}: 5)\end{array}$ & $\begin{array}{c}\text { Patient } \\
\text { (n:5) }\end{array}$ & $\begin{array}{l}\text { Total } \\
(\mathrm{n}: 15)\end{array}$ \\
\hline & n (\%) & n (\%) & n (\%) & n (\%) \\
\hline \multicolumn{5}{|l|}{ Gender } \\
\hline Male & $1(\% 20)$ & $2(\% 40)$ & $2(\% 40)$ & $5(\% 33,3)$ \\
\hline Female & $4(\% 80)$ & $3(\% 60)$ & $3(\% 60)$ & $10(\% 66,7)$ \\
\hline \multicolumn{5}{|l|}{ Is it easy to use? } \\
\hline Yes & $3(\% 60)$ & $5(\% 100)$ & $4(\% 80)$ & $12(\% 80)$ \\
\hline Undecided & $2(\% 40)$ & - & $1(\% 20)$ & $3(\% 20)$ \\
\hline \multicolumn{5}{|l|}{ Is the content interesting? } \\
\hline Yes & $4(\% 80)$ & $4(\% 80)$ & $5(\% 100)$ & $13(\% 86.7)$ \\
\hline Undecided & $1(\% 20)$ & $1(\% 20)$ & - & $2(\% 13.3)$ \\
\hline \multicolumn{5}{|c|}{ Is it visually well designed? } \\
\hline Yes & $3(\% 60)$ & $5(\% 100)$ & $5(\% 100)$ & $13(\% 86.6)$ \\
\hline No & $1(\% 20)$ & - & - & $1(\% 6.7)$ \\
\hline Undecided & $1(\% 20)$ & - & - & $1(\% 6.7)$ \\
\hline \multicolumn{5}{|c|}{ Does it contain enough information? } \\
\hline Yes & $5(\% 100)$ & $5(\% 100)$ & $5(\% 100)$ & $15(\% 100)$ \\
\hline \multicolumn{5}{|c|}{ Is the information reliable? * } \\
\hline Yes & $5(\% 100)$ & $5(\% 100)$ & - & $10(\% 100)$ \\
\hline \multicolumn{5}{|c|}{ Would you recommend it to someone else? } \\
\hline \multirow[t]{5}{*}{ Yes } & $5(\% 100)$ & $5(\% 100)$ & $5(\% 100)$ & $15(\% 100)$ \\
\hline & $\overline{\mathbf{X}} \pm \mathbf{S D}$ & $\overline{\mathbf{X}} \pm \mathbf{S D}$ & $\overline{\mathbf{X}} \pm \mathrm{SD}$ & $\overline{\mathbf{X}} \pm \mathrm{SD}$ \\
\hline & Median & Median & Median & Median \\
\hline & (Min-Max) & (Min-Max) & (Min-Max) & (Min-Max) \\
\hline & $29.2 \pm 1.64$ & $42.0 \pm 10.49$ & $40.6 \pm 7.86$ & $37.3 \pm 9.22$ \\
\hline \multirow[t]{3}{*}{ Age (years) } & 28 & 46 & 40 & 32 \\
\hline & $(28-31)$ & $(30-54)$ & $(32-52)$ & $(28-54)$ \\
\hline & $20.0 \pm 0.00$ & $23.6 \pm 3.36$ & $11.8 \pm 2.86$ & $18.5 \pm 5.63$ \\
\hline \multirow[t]{2}{*}{ Education span (years) } & 20 & 25 & 12 & 20 \\
\hline & $(20-20)$ & $(18-26)$ & $(8-16)$ & $(8-26)$ \\
\hline \multirow{3}{*}{$\begin{array}{l}\text { Average points } \\
\text { (1 very poor- } 5 \text { very good) }\end{array}$} & $4.4 \pm 0.89$ & $4.8 \pm 0.45$ & $5.0 \pm 0.00$ & $4.7 \pm 0.59$ \\
\hline & 5 & 5 & 5 & 5 \\
\hline & $(3-5)$ & $(4-5)$ & $(5-5$ & $(3-5)$ \\
\hline
\end{tabular}

*This question was asked only to health professionals.

The suggestions and statements of the participants about the application were given in Table 2. The application was updated according to the evaluations and suggestions of the participants and made ready for the evaluation of its effectiveness on patients.

The developed application was created by going through two prototypes and a final product phase.
Created prototypes consisted of a total of 4 activity screens: information entry, food record, evaluation, and advice screens. In the final version of the application, a user manual screen was added in addition to these screens. The stages of the information entry screen were shown in Figure 1. The English translations of the Turkish words in the application were expressed with the red dash lines in Figure 1-4. 
Tablo 2. The suggestions and statements of the participants

\begin{tabular}{|c|c|}
\hline Dietitian 1 & $\begin{array}{l}\text { - Tulum cheese (traditional cheese ripened in a goatskin casing) and peanuts are not on the list. } \\
\text { - Preparing a user manual at the beginning of the page may be more beneficial for patients. }\end{array}$ \\
\hline Dietitian 2 & $\begin{array}{l}\text { - It is better if the search button is blank when entering the name of the food. } \\
\text { - If the food and portioning place are different in color, it is easier to distinguish. }\end{array}$ \\
\hline Dietitian 3 & - The application seems very useful for patients; thus, I do not have any problems or suggestions. \\
\hline Dietitian 4 & $\begin{array}{l}\text { - Purslane, red mullet, milk powder, starch, vermicelli, meat-free legumes meal (dry beans, chickpeas, and } \\
\text { peas), okra, spinach with olive oil should be added to the menu. } \\
\text { - Bread size should be specified as a thin slice. } \\
\text { - The biscuit should be specified such as cream or plain. } \\
\text { - Ready two or three-in-one coffees can be added to the menu. } \\
\text { - Chocolates can be specified in detail as milk chocolates, hazelnut or pistachio. }\end{array}$ \\
\hline Dietitian 5 & $\begin{array}{l}\text { - Menu should be in alphabetical order. } \\
\text { - The application can be made more visual; the background color can be a soft color. } \\
\text { - Cheese types can be expanded. } \\
\text { - Delete command can be changed to remove from the list. }\end{array}$ \\
\hline Doctor 1 & - Menu should be in alphabetical order. \\
\hline Doctor 2 & - The application can be made more visual; the background color can be a soft color. \\
\hline Doctor 3 & - Cheese types can be expanded. \\
\hline Doctor 4 & - Delete command can be changed to remove from the list. \\
\hline Doctor 5 & $\begin{array}{l}\text { - Application requires patient compliance; I recommend preinformation. } \\
\text { - There is no purslane and lentil noodle soup in meals, these can be added. }\end{array}$ \\
\hline Patient 1 & - Usage of the application is a little complicated, some explanation before use may be good. \\
\hline Patient 2 & - I do not know my urine output, I had trouble entering the information on the information screen. \\
\hline Patient 3 & $\begin{array}{l}\text { - The application is complicated to use at first, but it is noticed that it is easy to use later. The use of the } \\
\text { application can be explained. }\end{array}$ \\
\hline Patient 4 & $\begin{array}{l}\text { - I cannot estimate the amount of fat in meals in tablespoons. } \\
\text { - "Maximum" and "Consumed" expressions should be changed for understandable. }\end{array}$ \\
\hline Patient 5 & $\begin{array}{l}\text { - Menu can be grouped or sorted alphabetically. } \\
\text { - The bottom buttons are not visible. You need to notice and scroll down the page. }\end{array}$ \\
\hline
\end{tabular}

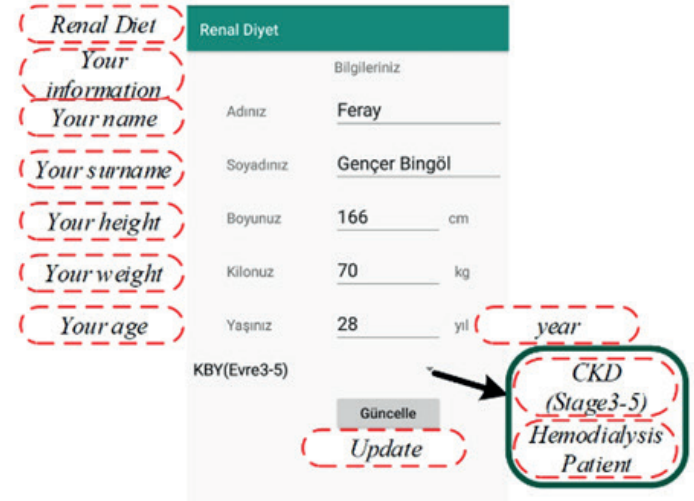

(a)

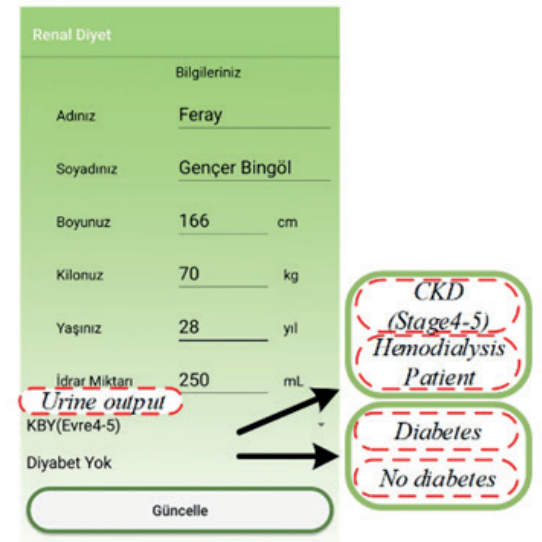

(b)

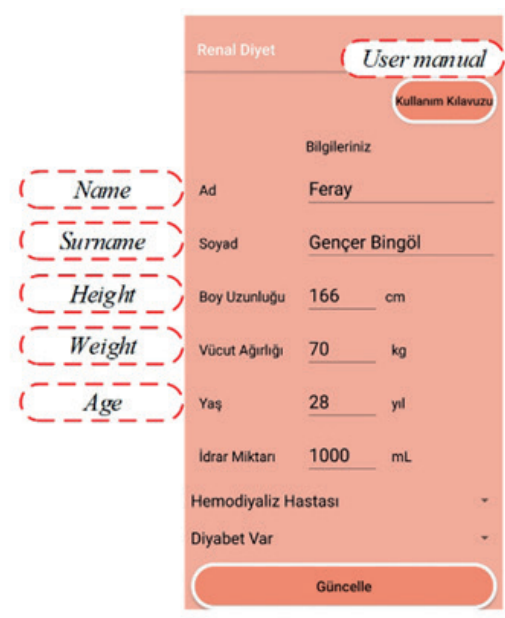

(c)

Figure 1. The stages of the information entry screen; (a) First prototype, (b) Second prototype, (c) Final product 
The CKD stage of the patients who could use the application between the first prototype and the second prototype was updated and corrected as could be seen in Figure 1. In addition, whether the patient has diabetes and the output of urine were added to the list on the information entry screen. Information such as "Your Height" instead of "Height" between the second prototype and the final product were arranged. Furthermore, the user manual button was added to the application in the final product. It was noticed that people had difficulty while using the application and this button was added to facilitate the use of the application in line with the suggestions of the participants. After clicking the Update button, the food record screen appears as in Figure 2.
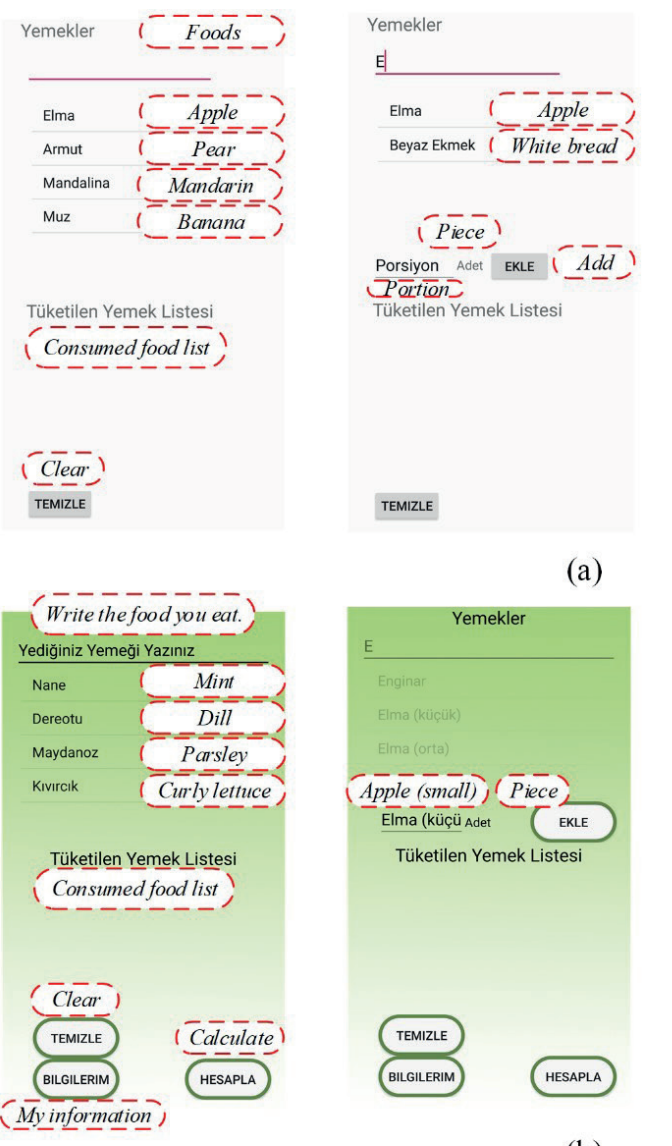

(a)

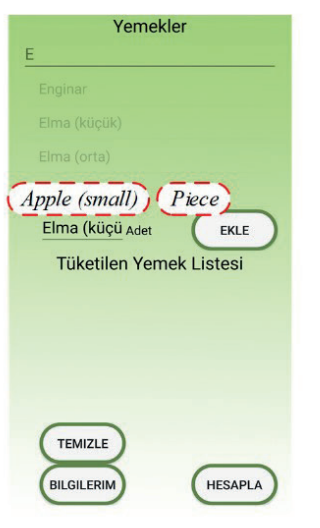

(b)

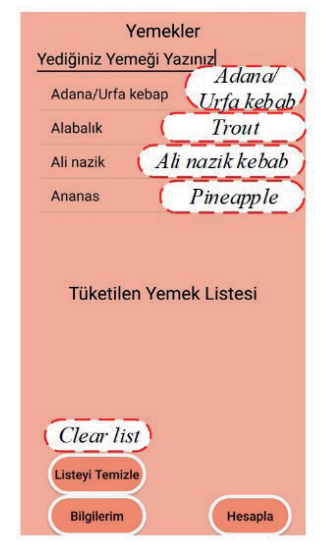

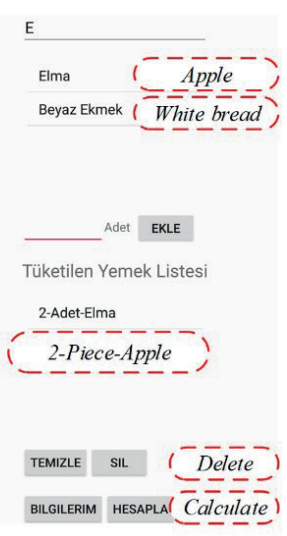

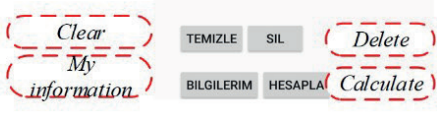
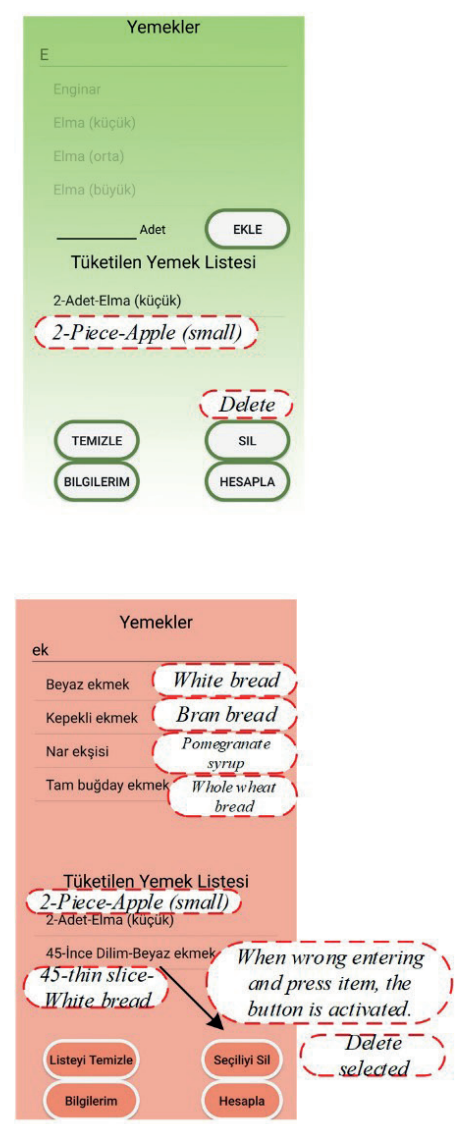

(c)

Figure 2. The stages of the food record screen; (a) First prototype, (b) Second prototype, (c) Final product 
The changes between prototypes of the food record screen were shown in Figure 2. Button locations shown as a deficiency in the first prototype were arranged in the second one. Following changes were applied between the prototypes; the objects were centered and the number of meals in the menu containing 13 foods were increased to 296. Finally, when the food is selected from the menu during the prototype development, the visibility of the list was changed. The difficulties experienced in the visibility adjustment of this menu have been eliminated in the final product. In the final product, the missing foods were determined as a result of the evaluation and the number of food was increased to 314 by adding the determined foods to the application. In line with the criticisms received that the selected food was difficult to perceive, the "Chosen Food" section was added to the amount addition section. In line with the same criticisms, the "Clear" and "Delete" buttons were changed to "Clear List" and "Delete Selected" to make them more understandable. Finally, the process of finding food from the list was simplified by listing the foods alphabetically. Development stages of the evaluation screen, which was activated when the "calculate" button was pressed, were shown in Figure 3.

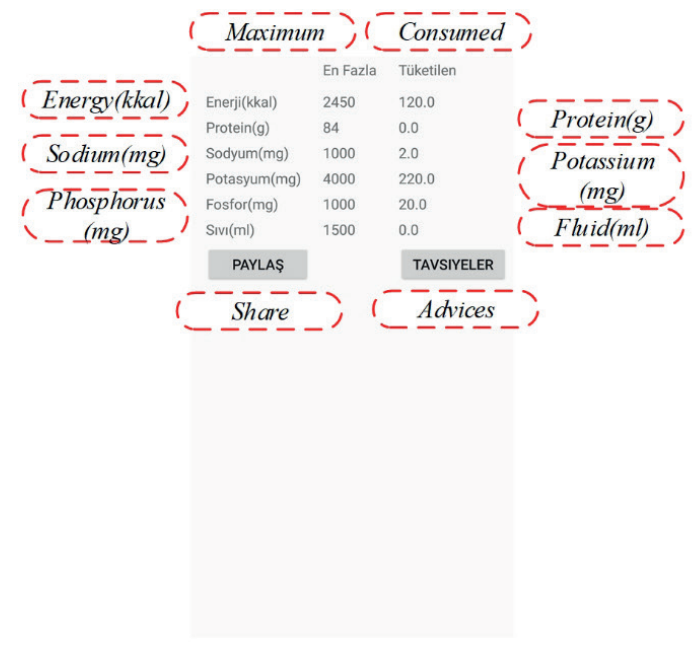

(a)

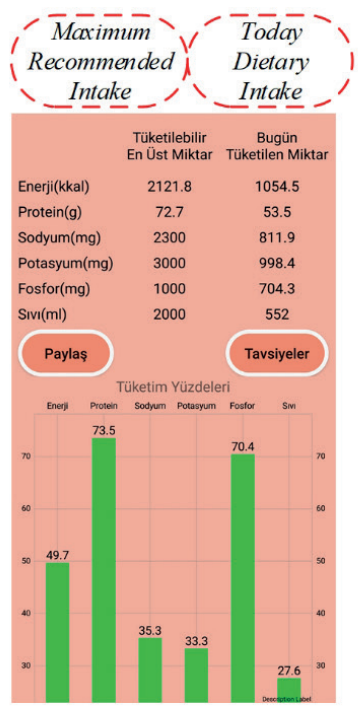

(c)

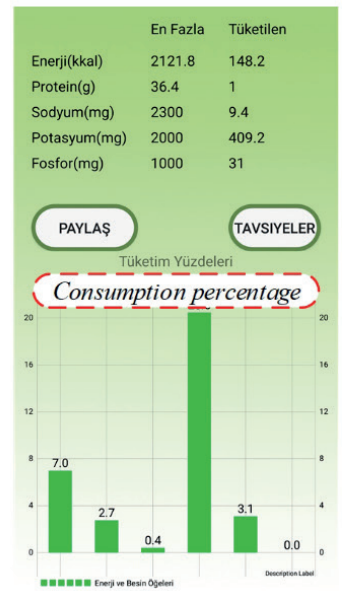

(b)

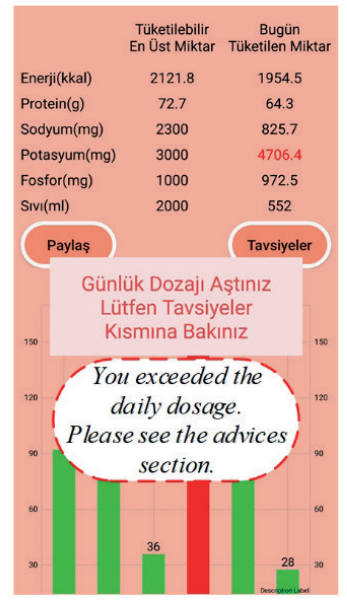

(d)

Figure 3. The stages of the evaluation screen; (a) First prototype, (b) Second prototype, (c) Final product in normal dietary intake, (d) Final product in exceeded dietary intake 
The updates between the prototypes of the evaluation screen were presented in Figure 3. While creating the second prototype from the first prototype, a graphic screen showing the dietary intake percentages was added. While creating the final product, it was criticized that when the daily dietary intake was exceeded, the warning could not be read owing to the small screen size. The enlarged warning balloon was placed in the middle of the screen to solve the problem as seen in Figure 3d. In addition, since it was stated during the evaluations that the expressions "Maximum" and "Consumed" are incomprehensible; instead "Maximum recommended intake" and "Today dietary intake" was used according to the interpretation. The development stages of the advice screen, which were activated when the advices button was pressed, were presented in Figure 4.

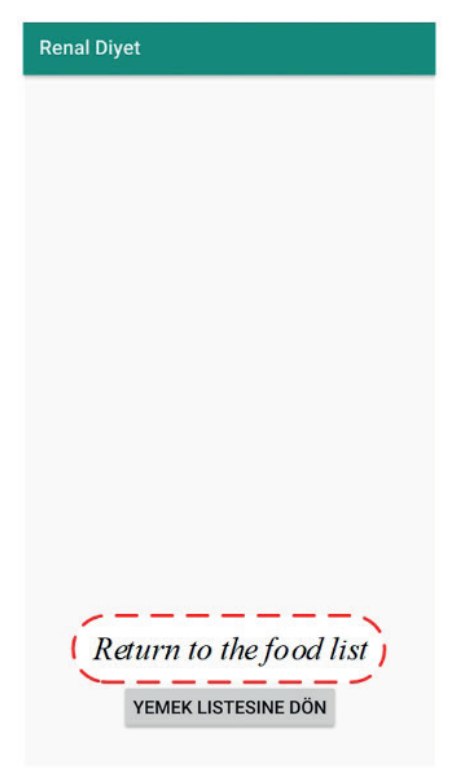

(a)

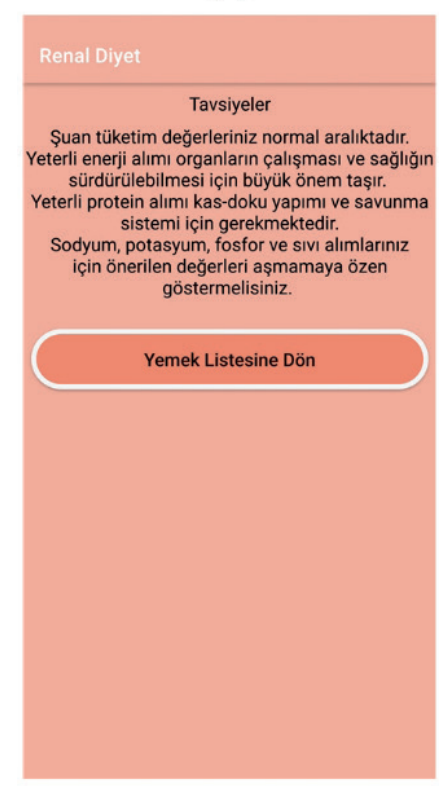

(c)

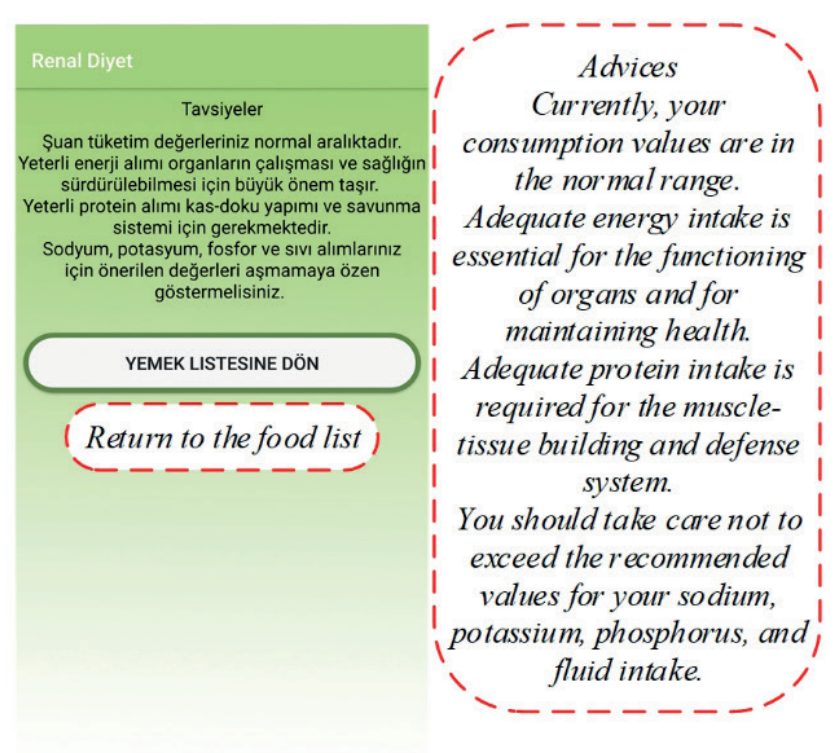

(b)

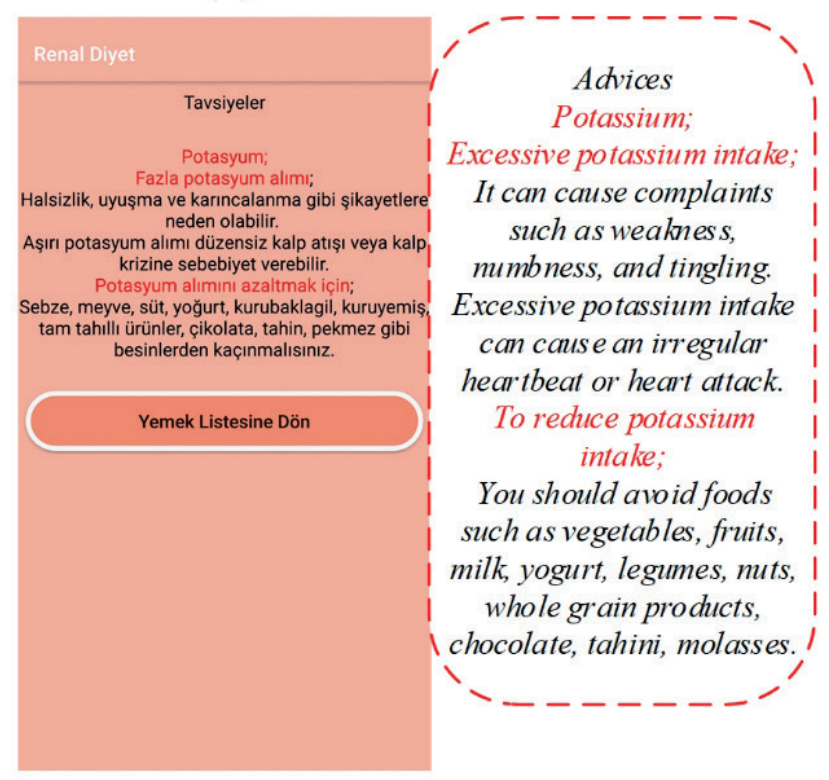

(d)

Figure 4. The stages of advices screen; (a) First prototype, (b) Second prototype, (c) Final product in normal dietary intake, (d) Final product in exceeded dietary intake 
The advices screen was left blank in the first prototype as could be seen in Figure 4a. Before the expert dietitian, specialist doctor, and patient evaluation stage, the advice information was added as shown in Figure $4 \mathrm{~b}$. Since no comments were received in the evaluations after this stage, the same screen was used as shown in Figure 4c-d.

Unlike the prototypes, a user manual was prepared according to the recommendations to integrate the final product. The user manual screen is the screen containing information about the usage of the application. This screen includes the use of the buttons in the application and the portion information of the foods. As a result of the evaluations, the development stages of the visual theme of the application could be divided into two parts as the visually of the buttons and the background. While a green to white image was used as the background visual between the first and second prototype, a pinkish color was used in the final product according to the recommendations. The button was updated visually according to the selected background color.

\section{DISCUSSION}

Chronic kidney disease patients quite often have difficulty in compliance with dietary restrictions that is an important part of the therapeutic approach for these patients. The burden of following guidelines and recommendations is important not only for the patients, but also for the families and caregivers of patients in need of care (17). With the widespread use of smartphones, these systems are also beginning to be used for the needs of patients. Careful monitoring of the intake of various nutrients is essential because metabolic abnormalities are common in CKD patients (18). Renal diet applications encourage patients to make better choices to increase their dietary compliance by comparing protein, sodium, potassium, phosphorus, and fluid contents of foods with other foods and recipes (9).

There are many mobile applications that were developed for CKD patients in app stores and these applications are mostly available in the English language. However, most of the current renal applications do not reflect evidence-based guidelines and information (19). This application was developed in the Turkish language taking into account evidencebased guidelines. In a systematic review by sing et al. (20), mobile applications related to 28 kidney diseases were examined. It has been determined that only 7 of these applications have monitoring and warning features and only 2 of these 7 applications warn the user when abnormal values are entered. The current application gives a warning when entering abnormal height and body weight values. In addition, when nutrient intake exceeds normal limits, the information turns red and patients are directed to the advices screen. It is seen that the applications developed are mostly created by individual developers instead of health professionals, health groups, and universities. This situation can pose a risk for both the health of the patients and the security of their personal information. Therefore, the safety of the information presented in mobile applications, the orientation of the patients, and the protection of the personal information are extremely important (21). This application is a mobile application developed by healthcare professionals. At this stage, raising awareness of reliable nutrition mobile applications and providing these options can encourage patients to use these applications. Mobile apps should not be expected to replace the expertise and social support provided by dietitians. However, these mobile apps can be useful in addition to nutritional counseling to improve the efficiency and quality of nutritional care (22).

There are different mobile applications and studies for CKD patients in the literature. Attitudes of the patients towards mobile nutrition applications were questioned in a study conducted in Canada. Ninety percent of the participants stated that they were interested in using the mobile nutrition application. In addition, the participants recommended that features such as portion sizes, weekly meal plans, CKDfriendly recipes could be included in the developed applications (23). In this study, the majority of the 
patients were interested in using the application and stated that they would recommend it to other patients since it is useful.

In a study conducted in Brazil, a mobile application was developed for self-management of dialysis patients. Patients were enabled to follow food intake, fluid intake, and medications using the application. It was seen that they could successfully control themselves with the mobile application and positive improvements were found in blood findings when the patients were evaluated with the medical condition self-management scale (18). Educational videos, recipes suitable for the disease, nutrient calculation screen, and laboratory findings monitoring screen were presented in another mobile nutrition application developed for hemodialysis patients (19). A dietary intake monitoring application in the USA was developed to be used on a personal digital. It is seen that the developed application has the feature of tracking the daily nutrient and fluid intake with its universal product code scanning, sound recording feature, and the content of the defined foods and meals (24). Another mobile application was developed to control the general health of CKD patients in a study conducted in Taiwan. Daily records (blood glucose, blood pressure, body weight), laboratory results and change graphs, diet and care information for each stage were provided to patients with the application. However, there is no detailed food consumption entry and control of daily intake in the application (25). Application developed in this study enables patients to control energy, protein, sodium, potassium, phosphorus, and fluid intake by entering daily food intake. In addition, patients see their daily intake on a graphic and are informed about what to do in case of excessive intake.

There are certain limitations in this study. The application is designed in the Turkish language for the use of patients in Turkey. For this reason, it cannot be used by patients not speaking Turkish. Furthermore, the developed application is compatible for Android users. For this reason, it cannot be used on phones with other operating systems.
As a result, the application developed in this study for CKD patients has received positive reactions and well received by healthcare professionals and patients. Additionally, it is thought that the changes made in line with the recommendations made the application better. In the next stage of the study, it is aimed to evaluate the effect of the developed application on the anthropometric measurements and biochemical findings along with food and fluid intake of the patients.

Author contributions - Yazarlık katkısı: Study design: FGB, MGK, MCB; Software: FGB, MCB; Data collection: FGB, YE; Data analysis: FGB, MCB; Draft preparation: FGB, $M C B$; Critical review for content: $M G K$, YE; Final approval of the version to be published: FGB, $M G K, M C B, Y E$. - Çalışmanin tasarım: FGB, MGK, MCB; Yazılım: FGB, MCB; Çalışma verilerinin elde edilmesi: $F G B, Y E$; Verilerin analiz edilmesi: FGB, MCB; Makale taslağının oluşturulması: FGB, MCB; İçerik için eleştirel gözden geçirme: $M G K, Y E$; Yayınlanacak versiyonun son onayl: $F G B, M G K, M C B, Y E$.

Ethics approval - Etik Kurul Onayl: The study was approved by the Gazi University Ethics Committee dated 09/05/2020. - Bu çalışma 09/05/2020 tarihli Gazi Üniversitesi Etik Komisyonu onayıyla yürütülmüştür.

Conflict of interest - Çıkar çatışmast: The authors declare that they have no conflict of interest. - Yazarlar çıkar çatışması olmadığın beyan ederler.

\section{REFERENCES}

1. Wetmore JB, Collins AJ. Global challenges posed by the growth of end-stage renal disease. Ren Replace Ther. 2016;2(1):1-7.

2. Pereira RA, Ramos CI, Teixeira RR, Muniz GAS, Claudino G, Cuppari L. Diet in chronic kidney disease: An integrated approach to nutritional therapy. Rev Assoc Med Bras. 2020;66(Suppl 1):59-67.

3. Kramer H, Jimenez EY, Brommage D, Vassalotti J, Montgomery E, Steiber A, et al. Medical nutrition therapy for patients with non-dialysis-dependent chronic kidney disease: Barriers and solutions. J Acad Nutr Diet. 2018;118(10):1958-65.

4. Statista. Mobil internet\&Apps. Available at: https://www. statista.com/statistics. Accessed July 3, 2020.

5. Gao C, Zhou L, Liu Z, Wang H, Bowers B. Mobile application for diabetes self-management in China: Do 
they fit for older adults? Int J Med Inform. 2017;101:6874.

6. Debon R, Coleone JD, Bellei EA, De Marchi ACB. Mobile health applications for chronic diseases: A systematic review of features for lifestyle improvement. Diabetes Metab Syndr Clin Res Rev. 2019;13(4):2507-12.

7. Paramastri R, Pratama SA, Ho DKN, Purnamasari SD, Mohammed AZ, Galvin CJ, et al. The use of mobile applications to improve nutrition behaviour: A systematic review. Comput Methods Programs Biomed. 2020;192:105459.

8. Fakih El Khoury C, Karavetian M, Halfens RJG, Crutzen R, Khoja L, Schols JMGA. The effects of dietary mobile apps on nutritional outcomes in adults with chronic diseases: a systematic review and meta-analysis. J Acad Nutr Diet. 2019;119(4):626-51.

9. Prest M. Mobile phone applications for kidney patients. J Ren Nutr. 2013;23(4):83-5.

10. Global Stats S. Mobile phone and tablet usage in Turkey. Available at: https://gs.statcounter.com/androidversion-market-share/mobile-tablet/turkey\#monthly202008-202008-bar. Accessed July 3, 2020.

11. Ikizler TA, Burrowes JD, Byham-gray LD, Campbell KL, Carrero JJ, Chan W, et al. KDOQI Clinical Practice Guideline for Nutrition in CKD: 2020 Update. Am J Kidney Dis. 2020;76(3):1-107.

12. Beslenme Bilgi Sistemi - BeBiS, Versiyon 7.0; 2019, Istanbul.

13. Baysal A, Kutluay-Merdol T, Ciğgerim N, Sacır H, Başoğlu S. Türk Mutfağından Örnekler. 4. Baskı. Ankara: Hatipoğlu Yayınevi; 2005.

14. Kutluay-Merdol T. Standart Yemek Tarifeleri. 4. baskı. Ankara: Hatipoğlu Yayınevi; 2011.

15. Gezmen-Karadağ M, Çelebi F, Ertaş Y, Şanlıer N. Geleneksel Türk Mutfağından Seçmeler: Besin Ögeleri Açısından Değerlendirilmesi. 1.Baskı. Ankara: Detay Yayıncllık; 2014.
16. Rakıcıoglu N, Acar Tek N, Ayaz A, Pekcan G. Yemek ve Besin Fotoğraf Kataloğu Ölçü ve Miktarlar. 3.Baskı. Ankara; 2012.

17. Siddique AB, Krebs M, Alvarez S, Greenspan I, Patel A. Mobile apps for the care management of chronic kidney and end-stage renal diseases: systematic search. JMIR Mhealth Uhealth. 2019;7:1-9.

18. Pinto LCS, Andrade MC, Chaves RO, Lopes LLB, Maués $\mathrm{KG}$, Monteiro AM, et al. Development and validation of an application for follow-up of patients undergoing dialysis: NefroPortátil. J Ren Nutr. 2020;30(4):51-7.

19. El Khoury CF, Karavetian M, Halfens RJ, Crutzen R, El Chaa, D, Schols JM, et al. Dietary application for the management of patients with hemodialysis: a formative development study. Healthc Inform Res. 2019;25(4):26273.

20. Singh K, Diamantidis CJ, Ramani S, Bhavsar NA, Mara P, Warner J, et al. Patients' and nephrologists' evaluation of patient-facing smartphone apps for CKD. Clin J Am Soc Nephrol. 2019;14:523-9.

21. Topf JM, Hiremath S. Got CKD? There's an app for that! Clin J Am Soc Nephrol. 2019;14:491-2.

22. Klein J. Utilization of mobile nutrition applications by patients with chronic kidney disease. J Ren Nutr. 2019;29(1):5-7.

23. Ene GEV, Lok C. An initial assessment of chronic kidney disease patients' needs for a mobile nutritional application. Am J Kidney Dis. 2018;71(4):536-7.

24. Welch JL, Siek KA, Connelly KH, Astroth KS, McManus MS, Scott L, et al. Merging health literacy with computer technology: Self-managing diet and fluid intake among adult hemodialysis patients. Patient Educ Couns. 2010;79(2):192-8.

25. Lin HW, Wang YJ, Jing LF, Chang P. Mockup design of personal health diary app for patients with chronic kidney disease. Stud Health Technol Inform. 2014;201:124-32. 